\title{
Application of Eclipta Leaves, Achras Zapota Leaves and Nyctanthes Arbortristis Flowers on Organic Cotton Fabric with Bio Wash
}

Manonmani G, Manimekalai $\mathbf{G}$ and Karpagam $\mathbf{P}^{*}$

PSG College of Arts and Science, Coimbatore, Tamil Nadu, India

\begin{abstract}
To rescue from the harmful effects of those chemical wastes the research work was focused on eco friendly natural dyes. The best in eco-friendly fabrics, "Organic cotton" was selected for the study. Extracted natural dyes from the selected natural resource (Eclipta Leaves, Achras Zapota Leaves and Nyctanthes Arbortristis Flowers) were applied onto organic cotton yarn with no using of chemicals \& mordents. Enzymatic Bio wash has been further done to the naturally dyed organic cotton fabric. The colorfastness properties of natural dyed organic cotton fabric were observed and concluded.
\end{abstract}

Keywords: Achras Zapot: Cellulase enzyme: Eclipta: Nyctanthes Arbortristis: Sapindus seeds

\section{Introduction}

Environmental issues are becoming more crucial all over world. Textile processing industry is characterized not only by the large volume of water required for various unit operations but also by the variety of chemicals used for various processes [1].

Organic cotton fabrics are generally understood as cotton that is grown from plants without chemical fertilizers or pesticides which are not genetically modified, though organic cotton has less environmental impact than conventional cotton and it costs more for its production $[2,3]$.

Natural dyes can exhibit better biodegradability and generally have a higher compatibility with the environment. Natural dyes are obtained from substances such as flowers, trees, shrubs, buries, lichens, shellfish, leaves, insects and minerals [4-8].

The three herbs Eclipta Leaves, Achras Zapota Leaves and Nyctanthes Arbortristis Flowers were selected since Eclipta leaves are anti toxicity in nature, Zapota leaves demonstrated character of antioxidant activity and Nyctanthes Arbortristis flowers has antiviral and antifungal activities in vitro [9-11].

Today enzymes have become an integral part of textile processing. Enzyme application is inevitable tool in modern industry where environmental aspect plays critical role to sustain in the competitive market. Enzyme (Cellulase) treatment gives the fabric a smoother and glossier appearance [4-8].

\section{Materials and Methods}

\section{Selection of yarn}

Organic cotton was purchased in yarn stage from the yarn dealer, Erode, Tamil Nadu which is of 80 s count since the end use is going to be used for baby wear. Fabric Specifications are shown in Table 1a.

\section{Methods}

\section{Scouring}

Scouring was done using Sapindus seeds without using of chemicals. Sapindus seeds (Figures 4a and $4 \mathrm{~b}$ ) were collected from Coimbatore Agricultural University. The sapindus seeds were dried under shade and ground to fine powder.
The scouring of organic cotton yarn was done in the bath with liquor ratio 1:20 with $5 \mathrm{~g} / \mathrm{l}$ of sapindus seeds solution (soap nut) using laboratory winch machine. The yarn was loaded into the bath at $400^{\circ} \mathrm{C}$ to $500^{\circ} \mathrm{C}$ for 3 hours. The yarn was then thoroughly washed with cold water and dried.

\section{Bleaching}

Catalase Enzyme is the bleaching agent which is chosen for the study to bleach the organic cotton yarn.

The bleaching of organic cotton yarn was done in the bath with liquor ratio 1:20 with catalase enzyme treated with $3 \%$ using laboratory winch machine. The bath was heated to $900^{\circ} \mathrm{C}$ and the yarns were bleached for 60 mins. The yarn was washed twice pin hot water and cold water.

\section{Selection of dye}

Eclipta leaves, Achras Zapota leaves and Nyctanthes Arbortristis

\begin{tabular}{|l|l|}
\hline Count & 80 s \\
\hline Loom & Pit loom \\
\hline Ends per inch & 76 \\
\hline Picks per inch & 43 \\
\hline Fabric Thickness & $0.28 \mathrm{~mm}$ \\
\hline Weave & Plain weave \\
\hline
\end{tabular}

Table 1a: Fabric Specifications.

\begin{tabular}{|l|l|l|}
\hline Colour fastness to washing & Change in colour & Staining \\
\hline Eclipta & 4 & 3 \\
\hline Achras Zapota & 4 & 3 \\
\hline Nyctanthes Arbortristis & 3 & 4 \\
\hline
\end{tabular}

NOTE: 1-Very poor, 2-Poor, 3-Medium, 4-Good, 5-Excellent Table 1b: Colour fastness to washing of dyed organic cotton fabrics.

*Corresponding author: P.Karpagam, PSG College of Arts and Science, Coimbatore, Tamil Nadu, India, Tel: 9578462862 E-mail: karpagam.psg@gmail.com Received February 07, 2013; Accepted May 29, 2013; Published May 31, 2013

Citation: Manonmani G, Manimekalai G, Karpagam P (2013) Application of Eclipta Leaves, Achras Zapota Leaves and Nyctanthes Arbortristis Flowers on Organic Cotton Fabric with Bio Wash. J Textile Sci Eng 3: 133. doi:10.4172/21658064.1000133

Copyright: (c) 2013 Manonmani G, et al. This is an open-access article distributed under the terms of the Creative Commons Attribution License, which permits unrestricted use, distribution, and reproduction in any medium, provided the original author and source are credited. 
flowers have been collected from Coimbatore area and it is used as natural eco friendly dyeing agent. The specified three (Eclipta leaves, Achras Zapota leaves and Nyctanthes Arbortristis flowers) herbs were selected (Figures 5a-5c).

These three herbs were selected because of the following aspects as per the literature review, Eclipta leaves are anti toxicity in nature, Zapota leaves demonstrated character of antioxidant activity and Nyctanthes Arbortristis flowers has antiviral and antifungal activities in vitro.

Main active principle constituents of Eclipta leaves are coumestans such as wedelolactone and demethylwedelolactone, polypeptides, polyacetylenes, thiophene derivatives, steroids, triterpenes and flavonoids, Structure of wedelolactone is shown in Figure 1 and the structure of Zapota leaves in Figure 2.

Chemical constituents of Nyctanthes arbor-tristis flowers (Figure 3) contain essential oils, nyctanthin, D-mannitol, tannins, glucose, carotenoids, glycosides including $\beta$-monogentiobioside ester of $\alpha$-crocetin (or crocin-3), $\beta$-monogentiobioside- $\beta$-D monoglucoside ester of $\alpha$-crocetin, and $\beta$-digentiobioside ester of $\alpha$-crocetin (or crocin-1).

\section{Extraction of natural dye solution from Eclipta}

250 gms of Eclipta leaves are shadow dried and ground well to fine powder. 1 liter of boiling water was added to the finely powdered dried eclipta leaves for about 2-3 hours. Then it is filtered using nylon cloth<smiles>COc1cc(O)c2c(c1)oc(=O)c1c3c(oc12)CC(O)C(O)=C3</smiles>

\section{wedelolactone (4)}

Figure 1: Wedelolactone Structure.<smiles>O=C(/C=C/c1ccc(O)c(O)c1)OC1C(O)CC(O)(C(=O)O)CC1O</smiles>

Figure 2: The chemical structure of Zapota leaves.

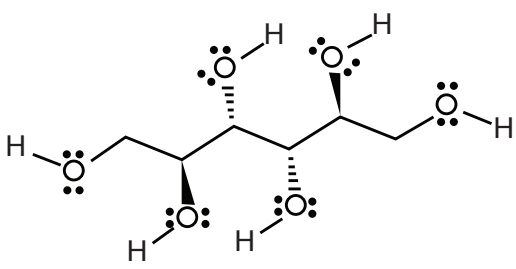

Figure 3: Chemical constituents of Nyctanthes arbor-tristis flowers.

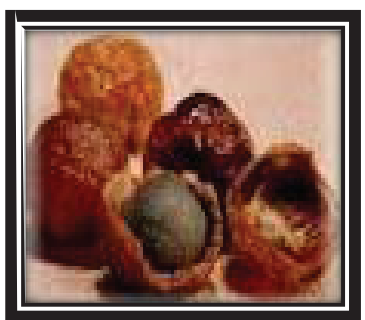

Figure 4a: Sapindus Seeds.

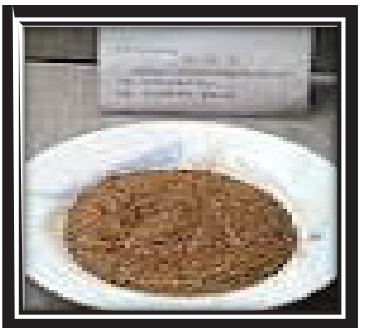

Figure 4b: Sapindus Seeds Powder.

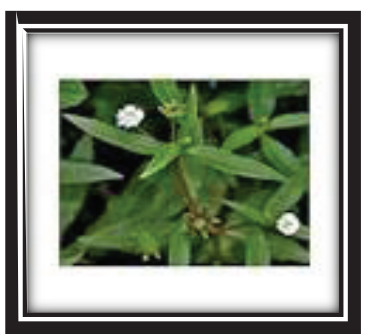

Figure 5a: Eclipta Leaf.

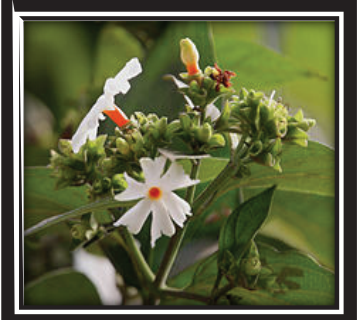

Figure 5b: Nyctanthes Arbortristis flowers.

\section{Extraction of natural dye solution from Achras Zapota}

Achras Zapota fresh leaves were boiled in 1 litre of water for about 2-3 hours. Then it is filtered using nylon cloth.

\section{Extraction natural dye solution from Nyctanthes Arbortristis}

Nyctanthes Arbortristis fresh flowers were boiled in 1 litre of water for about 2-3 hours. Then the extracted dye solution is filtered using nylon cloth.

\section{Application of Natural Dyes on Organic Cotton Yarn}

The dyeing of organic cotton yarn was done in the bath with liquor ratio 1:20 with $10 \mathrm{gpl}$ of dye solution using Laboratory winch dyeing machine. The yarn was loaded into bath at $900^{\circ} \mathrm{C}$ to $1200^{\circ} \mathrm{C}$ for $2-3$ 


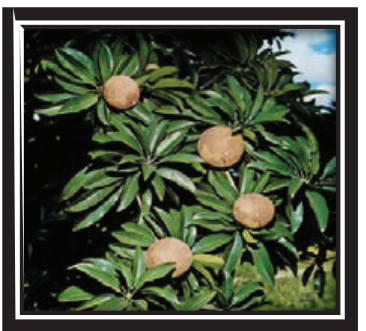

Figure 5c: AchrasZapota leaf.

\begin{tabular}{|l|l|l|}
\hline Colour Fastness to Rubbing & Dry & Wet \\
\hline Eclipta & 4 & 3 \\
\hline Achras Zapota & 3 & 4 \\
\hline Coral jasmine & 3 & 4 \\
\hline
\end{tabular}

NOTE: 1-Very poor, 2-Poor, 3-Medium, 4-Good, 5-Excellent

Table 2: Colour fastness to rubbing of dyed organic cotton fabrics.

\begin{tabular}{|l|l|l|}
\hline Colour fastness to Sun light & Change in colour & Staining \\
\hline Eclipta & 4 & 3 \\
\hline Achras Zapota & 4 & 3 \\
\hline Nyctanthes Arbortristis & 3 & 4 \\
\hline
\end{tabular}

NOTE: 1-Very poor, 2-Poor, 3-Medium, 4-Good,5-Excellent

Table 3: Colour fastness to sunlight of dyed organic cotton fabrics.

hours. The dyed yarn was washed thoroughly in cold water and then squeezed and shade dried.

\section{Hand loom weaving}

The yarn is then woven into fabric using pit loom.

\section{Bio wash}

Cellulase Enzyme is the washing agent which is chosen for the study for the bio wash process of dyed organic cotton fabrics.

The bio washing of organic cotton fabrics was done in the bath with the liquor ratio 1:15 with $3 \mathrm{gpl}$ of Cellulase Enzyme using laboratory washing machine. The fabric was loaded into the bath at $450^{\circ} \mathrm{C}$ to $550^{\circ} \mathrm{C}$ for 10 minutes. The sample washing was repeated for 5 times and then, the samples were rinsed three times in de-ionized water. Finally, the samples were left to dry at room temperature for 24 hours.

\section{Evaluation of color fastness}

Colorfastness to washing: Wash fastness of all dyed samples was measured by the ISO 105-C03 testing method. Dyed samples were taken, stitched with one of the shorter side of the adjacent bleached fabric and was put to the bath containing $3 \mathrm{gpl}$ of soap, $2 \mathrm{gpl}$ of sodium carbonate and 1:30 MLR ratio at $60^{\circ} \mathrm{C}$ for 30 minutes. Then the specimen was washed with hot water, cold water and then it was dried. Then the dried fabrics were evaluated for color change and staining using grey scale.

Colorfastness to rubbing: Rubbing fastness of all dyed samples was measured by dry and wet rubbing method. The dyed sample was fastened to the flat base of the crock meter and the bleached $100 \%$ cotton measuring $5 \mathrm{~cm} \times 5 \mathrm{~cm}$ was mounted on the rubbing finger. After mounting the samples, the handle was rotated to ten complete turns at the rate of one turn per second to slide the covered finger back and forth twenty times. Then both the dyed and bleached fabric was evaluated with the grey scale for color change and staining.
Colorfastness to sunlight: Sunlight fastnesses of all dyed samples were exposed to sun for a period of time and then compared with an unexposed sample. A sample size of $35 \mathrm{~cm} \times 12 \mathrm{~cm}$ was cut from dyed organic cotton fabrics. The sample was divided into nine equal parts and marking was made on it. The strip was covered with a black chart papers, marked with equal number of divisions. First division was cut and exposed on sun light. The second division was cut and exposed on sun light and so on. Finally the first division after exposure for seven days was assessed for colour change in comparison with the original using a grey scale rating.

\section{Results and Discussion}

\section{Colour fastness to washing}

Colour fastness to washing of Eclipta, Achras Zapota and Nyctanthes Arbortristis dyed organic cotton fabric is shown in the Table 1b. It is found that the dyed sample shows good colour fastness.

\section{Colour fastness to rubbing}

Colour fastness to rubbing of Eclipta, Achras Zapota and Nyctanthes Arbortristis dyed organic cotton fabric is shown in Table 2. It is found that the dyed sample shows good colour fastness.

\section{Colour fastness to sun light}

Colour fastness to Sunlight of Eclipta, Achras Zapota and Nyctanthes Arbortristis dyed Organic cotton fabric is shown in Table 3. It is found that the colour fastness to sunlight of dyed Eclipta, Achras Zapota and Nyctanthes Arbortristis performed to be best.

\section{Conclusion}

Organic cotton is an eco-friendly fiber that suits for children wear. The natural dyeing is carried out in yarn stage to enhance the durability of dyeing. Then bio wash is given to soften the fabric.

The scouring and bleaching process was carried out onto the organic cotton yarn. Then the organic cotton yarn is dyed with natural dyes without adding mordant and chemicals. The dyed organic cotton yarn is woven into plain weave structure in handloom weaving machine. The bio washing process is carried over the dyed organic cotton fabric.

Natural dyeing eliminates the harmful effect of dye powder and prevents the skin from allergies and rashes. It is found that all the three Natural dyed organic cotton fabric shows good in color fastness to Washing, Rubbing and Sunlight.

\section{References}

1. Arora A (2009) Textbook of Dyes. Sonali Publications, India

2. Bhattacharya, SD, Patel DD (2004) Finishing and simultaneous dyeing of cotton fabric. Indian Tex J 144: 13-18.

3. Edward Menezes (2007) Organic Cotton Processing. New Cloth Market 21 $37-41$.

4. Goodsell DS (2007) Catalase, Molecule of the Month. Pearson Edition 2: 16

5. Parvathi C, Maruthavanan T, Pandit, Prakash RV (2009) Environmental impacts of textile industries. The Indian Textile Journal 22.

6. Puri A, Saxena R, Saxena RP, Saxena KC, Srivastava V, et al. (2002) Immunostimulant activity of Nyctanthes arbor-tristis L. J Ethnopharmacol 42 31-37.

7. Saxena RS, Gupta B, Lata S (2002) Tranquilizing, antihistaminic and purgative activity of Nyctanthes arbor tristis leaf extract. J Ethnopharmacol 81: 321-325. 
Citation: Manonmani G, Manimekalai G, Karpagam P (2013) Application of Eclipta Leaves, Achras Zapota Leaves and Nyctanthes Arbortristis Flowers on Organic Cotton Fabric with Bio Wash. J Textile Sci Eng 3: 133. doi:10.4172/2165-8064.1000133

Page 4 of 4

8. Bayer EA, Chanzy H, Lamed R, Shoham Y (2009) Cellulose, Cellulases and Cellulosomes. Curr Opin Struct Biol 8: 548-557.

9. Senthil Kumar (2007) Organic cotton: A route to eco-friendly textiles. Indian Tex J 118:21-25.
10. Sharma N K (2008) Market ecology and organic cotton. Indian Tex J 119: 40-45

11. Stoffels, Karin (2008) Soap Nut Saponins Create Powerful Natural Surfactant. Personal Care Magazine. 